\title{
Making the Administrative Law Enforcement in Indonesia Effective as an Effort to Prevent Violations Reclamation and Post-Mining Obligations (Study in East Kalimantan Province)
}

\author{
Muhammad Bagus Adi Wicaksono ${ }^{1}$, I Gusti Ayu Ketut Rachmi Handayani ${ }^{2}$, Lego Karjoko ${ }^{3}$ \\ ${ }^{1.2 .3}$ Universitas Sebelas Maret \\ Surakarta, Indonesia \\ mbaw@student.uns.ac.id
}

\begin{abstract}
This study has purpose to provide input and suggestions regarding the concept of an effective administrative law enforcement system to prevent violations of reclamation and post-mining obligations in East Kalimantan Province. This study was a non-doctrinal legal research that analyzes the effectiveness of the law regarding the regulation of reclamation and post-mining obligations as regulated in Law Number 4 of 2009 concerning Mineral and Coal Mining. An effective administrative law enforcement system to prevent violations of reclamation and post-mining obligations in East Kalimantan Province is as follows, a. Fixing regulations regarding reclamation and post-mining obligations, it must be carried out without leaving the mining pit. b. Optimizing the role of the Mining Inspector and the Department of Energy and Mineral Resources of the Province of East Kalimantan by adding the human resources, operational budgets, facilities and infrastructure as well as accelerating the recapitulation of documents due to the transfer of mining authority from the Regency or City level to the Provincial Level. c. Efforts to eliminate the bad habits of coal mining entrepreneurs aside from providing guidance to the coal mining entrepreneurs related to reclamation and post-mining obligations carried out by the Mining Inspector and the Department of Energy and Mineral Resources to the coal entrepreneurs that the closure of the mining pit must be carried out as a reclamation and post-mining activity and it is able to be done by involving the surrounding community in monitoring the reclamation and post-mining activities.
\end{abstract}

Keywords- Reclamation, Mining, Administrative Law Enforcement.

\section{INTRODUCTION}

Mining is an activity that includes the extraction and preparation for further processing of solids, liquids and gases. Mining or excavation is an attempt to explore the various potentials contained in the body of the earth. Mining activities, including prospecting, exploration, construction, operation, maintenance, expansion, abandonment, decommissioning and repurposing of a mine can impact social and environmental systems in a range of positive and negative, and direct and indirect ways. Mining can yield a range of benefits to societies, but it may also cause conflict, not least in relation to above-ground and sub-surface land use. Similarly, mining can alter environments, but remediation and mitigation can restore systems. Mining business is an activity to optimize the utilization of mining natural resources (excavated materials) contained in the earth. The mining sector has special characteristics, among others, requires large capital, uses modern technology, is carried out by experts, is high risk, slow returns on capital and is sensitive to changes in the situation.

Kalimantan is the largest island that has natural resources, particularly in the energy and mining sectors. In accordance with the condition of resources and geography of Kalimantan Island, the Central Government has designated this area as a center for production and processing of mining products as well as a national energy barn in the MP3EI (Masterplan for the Acceleration and Expansion of Indonesian Economic Development). According to the data processed by the Central Statistics Agency (BPS) shows that the main support for the economy of the Kalimantan corridor is the oil and gas sector and the mining sector contributes about $50 \%$ of the total GRDP (Gross Regional Domestic Product) of Kalimantan. This island has coal reserves of 51.9 billion tons or $49.6 \%$ of Indonesia's resources, the second largest exploitation and oil and gas industry in Indonesia after the Cepu block.

Currently, the largest number of coal mining activities on the island of Kalimantan is in the province of East Kalimantan where there are 379 mining business permits (IUP), so that it is one of the provinces that contribute the largest economy to the Indonesian state compared to other regions on the island of Kalimantan. Supported by the economic growth of the district or city which is growing rapidly in the coal mining sector, oil and gas exploitation and the oil and gas industry. Based on the data from the Director General of Mineral and Coal in 2009, the portion of coal reserves in Kalimantan is almost 50 percent of the national coal reserves in Kalimantan. More than 70 percent of Kalimantan's coal reserves are concentrated in the province of East Kalimantan. Thus, the average regional income of the Regency Government in East Kalimantan is above 40 percent from coal mining. 
In this regard, the increasing number of mining business permits (IUP) issued by the Provincial Government of East Kalimantan will also have an impact on the environmental balance around mining sites if there is no law enforcement effort. Coal mines are exploited on a large scale, will cause deforestation, bare land with holes like giant puddles, ecologically very worrying since it causes environmental damage. Environmental damage based on Article 1 number 17 of Law Number 32 of 2009 concerning Life Protection and Management is a direct and/or indirect change to the physical, chemical, and/or biological characteristics of the environment that exceeds the standard criteria for environmental damage.

Thus, it can be said that the coal mining business activities in East Kalimantan Province which ignore the environmental sustainability are not in line with Article 33 Paragraph 4 of the 1945 Constitution of the Republic of Indonesia which mandates that the national economy is organized based on the economic democracy with the principles of togetherness, efficiency with justice, sustainable, environmentally friendly, independent, and by maintaining a balance of progress and national economic unity as well as Article $28 \mathrm{H}$ paragraph (1) which regulates a person's right to live in physical and spiritual prosperity, to have a place to live, and to have a good and healthy living environment and have the right to get health services. In the practice, the ideal part in Article 33 paragraph 4 and Article $28 \mathrm{H}$ paragraph (1) of the 1945 Constitution turns out to be far from expectations, since there are still many coal mining activities that cause the environmental damage in East Kalimantan Province so that people do not obtain a healthy living environment.

Law Number 4 of 2009 concerning Mineral and Coal Mining mandates that mineral and/or coal mining is managed on a sustainable basis and with an environmental perspective, so that every business actor or coal mining activity is required to carry out reclamation and post-mining as an effort to restore environmental functions as they should. Reclamation is an activity carried out throughout the stages of the mining business to organize, restore, and improve the quality of the environment and ecosystem so that it can function again according to its designation. Meanwhile, post-mining activities, hereinafter referred to as post-mining, are planned, systematic, and continuing activities after the end of part or all of the mining business activities to restore the natural environment and social functions according to the local conditions throughout the mining area.

The fact shows that the coal mining entrepreneurs have not carried out their reclamation and post-mining obligations until now, so that many puddles or ex-mining holes (voids) are still gaping and claiming lives. Tribunkaltim.com, Already 36 victims died in the mining pit, the Islamic Student Association (HMI) of Samarinda City stated that the East Kalimantan Provincial
Government was not serious in handling the coal mining activities, Head of the environmental sector of the Samarinda City Islamic Student Association (HMI), Nur Hariyani stated, since the last four months, starting in April, May, June and August 2019, there have been four deaths, both children and adults. However, until now there has been no concrete solution from the provincial government and the Department of Energy and Mineral Resources of East Kalimantan Province regarding the completion of the gaping mining pit," as stated to Tribunkaltim.com, Then, the place seems to have been left alone, based on the data from the East Kalimantan Mining Advocacy Network, East Kalimantan currently has around 1,735 holes that are left gaping as if they have no owner. It is also stated that the Provincial Government of East Kalimantan and the Department of Energy and Mineral Resources must be responsible for handling mining pits. Considering one of the news exposures in the mass media, it is necessary to enforce the law so that the legal issue can be resolved.

In this context, it is the enforcement of administrative law; the question is how the steps that should be taken to make the enforcement of administrative law more effective.

\section{RESEARCH METHOD}

The type of research used in this study was an empirical legal research or non-doctrinal legal research. Legal research was conducted to produce new arguments, theories or concepts as prescriptions in solving problems at hand. Legal research is a scientific activity, which is based on certain methods, systematics and thoughts, which aims to study one or several certain legal phenomena, by analyzing them. This study was included in the type of research that examines the implementation of a legal regulation regarding the activities of reclamation and post-coal mining obligations related to environmental damage in East Kalimantan Province.

\section{FINDINGS AND DISCUSSION}

Mining business activities from an economic point of view are indeed very profitable for the nation and the state since they have a very high selling value in the world market. In principle, people who carry out mining business activities are those who carry out mining by digging soil to get mining products and then selling them and making a profit. Although mining activities have a good impact, on the other hand, it can also have a bad impact on the environment. The result of mining is that the land cannot return to its original state, even though reclamation has been carried out. The land from the former mining is also difficult to be planted with plants since the land resources are no longer there, the soil becomes infertile. The impact on bare land is that if it is exposed to rain, the land will become landslides and cause flooding so that the community itself suffers losses. This is a bit of the relationship between mining and the environment, that mining activities are very vulnerable to 
environmental damage if the perpetrators cannot properly manage the surrounding environment.

The obligation of business entities in conducting reclamation and post-mining according to Law Number 4 of 2009 concerning Mineral and Coal Mining must be carried out as a form of compliance and obedience of business entities to the applicable legal provisions and the responsibility of business entities to the nation and state to maintain and preserve the environment after conducting the mining business. If the business entity does not carry out the obligation to carry out reclamation and postmining, then the implementation of administrative sanctions toward the business entity needs to be enforced in accordance with the applicable laws and regulations to provide the legal certainty so that other business entities will no longer perform the same act. Enforcement of administrative law through administrative sanctions such as warnings, government coercion, forced money, administrative fines, permit suspension and license revocation is a strategy that is more in line with the threat based compliance strategy. Ideally, the use of administrative sanctions (threat based) is combined with coaching actions or technical guidance by agencies in the environmental sector to achieve an optimal level of compliance.

Considering the discussion of the factors that cause ineffective administrative law enforcement so that coal mining activities do not carry out reclamation and postmining obligations as an effort to manage and control the environment, the writer provide prerequisites on how the administrative law enforcement should be implemented so that it is effective in preventing the environmental damage in East Kalimantan Province. The writer applied three theories; those are theories regarding the effectiveness of the law, compliance, and government readiness in implementing administrative law enforcement. The three theories complement each other so that they can provide guidance on how to enforce the effective administrative law, including:

\section{Fixing Regulations Regarding Reclamation and Post- Mining Activities}

It is true that Article 96 of the Law of the Republic of Indonesia Number 4 of 2009 concerning Mineral and Coal Mining has regulated the application of good mining engineering principles, where holders of mining business permits (IUP) and special mining business permits (IUPK) are required to carry out reclamation and postmining activities as an effort to manage and monitor the mining environment. Then, Article 100 paragraph 1 states that IUP and IUPK holders are required to provide reclamation guarantee funds and post-mining guarantee funds. However, the problem is when Article 101 of Law Number 4 of 2009 concerning Mineral and Coal Mining states that further provisions regarding reclamation and post-mining as well as reclamation guarantee funds and post-mining guarantee funds are regulated by the government regulations. The existing government regulations and their derivatives are actually mining holeproducing regulations and provide an option so that the coal mining entrepreneurs do not carry out reclamation and post-mining since the operational costs of closing mine pits are expensive. Government regulations and their derivatives have been described in the sub-chapter the factors inhibiting the enforcement of administrative law above.

In the book Panorama of Law and Legal Studies, Bernard L Tanya \& Theodora Y Parera mentions that in the rule of law that is not qualified, it will be prone to deviations in the pathological structure [4]. According to the authors of the book, the legal pathological seeds have started since a regulation was initiated. Very often, the making of a rule of law is driven by a momentary emotional reactive attitude without considering its relevance and significance in the wider context. In addition, sometimes the making of academic drafts is often done quickly and is only considered a legal drafting project, even though the content of the rules is much wider and richer that requires careful review and must involve as many related experts as possible.

Meanwhile, considering Indonesia as a state of law, all aspects of life in the social, national and state fields including government must be based on laws that are in accordance with the national legal system. As stated by Maria Farida in a state based on modern law, the main purpose of the formation of laws is no longer to create a codification of norms and values that have settled in the society, but the main purpose of the formation of laws is to create modifications (modify) or changes that occur in the lives of the people [5]. Thus, according to the writer, the Indonesian government, particularly the regional government of East Kalimantan Province, has made special regulations in accordance with the main regulations, namely the Law of the Republic of Indonesia Number 4 of 2009 concerning Mineral and Coal Mining which requires coal mining entrepreneurs to carry out reclamation and post-mining activities in order to prevent the environmental damage.

The definition of reclamation itself is an activity carried out throughout the stages of the mining business to organize, restore, and improve the quality of the environment and ecosystem so that it can function again or be reused according to its designation, then postmining activities, hereinafter referred to as post-mining, are planned, systematic, and continuous activities after the end or part or all of mining business activities to restore the natural environmental functions and social functions according to the local conditions throughout the mining area. This understanding clearly mandates that the former coal mining activity environment can function again according to its designation and not for other purposes such as tourism, settlements or so on. 
Yuliandri stated that the legal policy as outlined in the law became a means of social engineering, which contained the policies that the government wanted to achieve, to direct the public to accept new values [6]. Meanwhile, Hattu stated that in a modern legal state requires the formation of laws and regulations that function as instruments to provide, regulate, limit and supervise the implementation of the duties and authorities of the Government and guarantee the rights of the people [7]. Based on this, the government is advised to immediately establish a legal regulation in order to provide legal certainty to support and be able to apply Article 100 Paragraph (2) of Law Number 4 Year 2009 concerning Mineral and Coal Mining, so that there are implementing regulations regarding technical implementation guidelines. the appointment of a third party by the government to carry out reclamation and post-mining if the IUP or IUPK holder does not carry out the reclamation and post-mining in accordance with the approved plan.

The writer also adds that all derivative regulations from Law Number 4 of 2009 concerning Mineral and Coal Mining do not allow the coal mining entrepreneurs to leave a few percent of mining holes, the government is expected that the closure of these mining holes must be $100 \%$ (one hundred percent) closed, given that the impact of the former mining pits that are not closed can cause the environmental damage and the loss of life.

\section{Optimizing the Role of Mining Inspectors and the Department of Energy and Mineral Resources of East Kalimantan Province}

When talking about the legal structure, it will refer to the management, personnel, and infrastructure in the organization of legal institutions. Furthermore, studies in the area of the legal structure sub-system may include: 1 . Legal institutions (in terms of rules, management, architecture, geography, history, etc.), 2. Judicial structures and mechanisms (in terms of rules, economy, power, administration), social and cultural), 3. Law enforcement personnel (in terms of power and formal authority, psychological, skills, ethos, biological aspects, value orientation, income and educational background, etc.), 4. Legal facilities and infrastructure (from in terms of quantity, quality, usability, benefits, efficiency and others). In this study, what is meant by the legal structure here is the relevant stakeholders who play a role in carrying out the legal actions or any behavior carried out by anyone who has the authority, who acts in a legal system to carry out guidance, supervision and imposition of administrative sanctions on the coal mining activities in the province of East Kalimantan, namely the Mining Inspector and the Department of Energy and Human Resources.

The writer provides a solution for the East Kalimantan Provincial Government to increase the number of Mining Inspector human resources which aims to detect, respond to, and impose sanctions optimally and increase the amount of budget adequacy by the government to carry out the administrative law enforcement (budget allocation) as well as additional facilities and infrastructure. This needs to be done by the East Kalimantan Provincial Government so that it is optimal in carrying out the administrative law enforcement so that it is effective in preventing the environmental damage in East Kalimantan Province caused by the coal mining companies that do not carry out reclamation and postmining obligations and able to carry out routine and periodic supervision. Routine supervision is a persuasive corrective action that provides the widest possible space for regulators to conduct compliance checks, and provide counseling and technical assistance to the regulatee to improve its performance to the level of compliance in accordance with the laws and regulations. Persuasion carried out by the government officials includes persuasion carried out if violations are found during routine or incidental inspections that require corrective action. This form of persuasion requires the readiness of human resources, especially human resources at the district/city level. The readiness of human resources includes readiness in terms of quantity (adequacy of the number of supervisors compared to the companies being supervised) and quality (ability to detect violations and carry out technical guidance), as well as the integrity of government officials.

The writer also suggests that regarding the transfer of authority from the Regency or City Level to the Provincial Level, it is necessary to evaluate or recapitulate documents explicitly regarding the coal mining in East Kalimantan Province between the Regency or City government and the East Kalimantan Provincial government since the enactment of 23 of 2014 concerning Regional Government. This is done so that the delegation of supervisory authority and the imposition of administrative sanctions in East Kalimantan Province is clear and well structured.

\section{Guidance for Coal Mining Entrepreneurs regarding Reclamation and Post-Mining Obligations}

Building and realizing law in people's lives will certainly be faced with various challenges, both caused by the internal and external factors of the community itself. Undoubtedly, the law will be good if people accept it voluntarily. On the other hand, the law will be bad if the community cannot accept it, since it cannot protect the interests of the community. Thus, the law and the interests of the community must have a balance, in the sense that the law was created to protect the interests of the community. Society and culture are nothing but a dual in the elements of legal culture that have an important influence in the operation of a large system, called the legal system. Thus, it is not surprising that the legal experts stated that legal culture and awareness are the only source and binding force of law. However, to increase the degree of the legal culture is not an easy 
matter. A task that is not easy, since the legal awareness of a nation comes from individual legal feelings and beliefs. Thus, efforts are needed to build the confidence of individuals in Indonesian society that the law is a reference milestone in this country.

Legal culture is not only a monopoly of society, in which there is the role of rulers and legislators as teachers who should deserve to be "trusted" and "imitated", as well as wise and of course virtuous. Not the other way around, just being an official who enjoys a seat by forgetting their duties and obligations as a public servant. As a result, there is a society that is out of control and uncontrollable, since the controller of the community, in this case state officials, forgets the community. In addition, the community only feels that they are used as objects of interest by officials, or used as cash cows that are used to satisfy the interests of the authorities. As a result, there is no longer legal awareness in the society; the law is only a passing wind that is ignored by the lower layers of society. Efforts to increase this understanding by providing guidance and also socialization to the community, especially the coal mining entrepreneurs, are carried out by the Regional Government that these reclamation and post-mining activities must be carried out by IUP and IUPK holders, then when they have deposited reclamation and post-mining guarantee funds, it does not eliminate the obligation for mining entrepreneurs to continue to carry out reclamation and post-mining activities and can also be done by involving the surrounding community in monitoring the reclamation and post-mining activities.

The writer adds that although many regulations regarding reclamation and post-mining activities overlap, the East Kalimantan Provincial Government must still be guided by the Law of the Republic of Indonesia Number 4 of 2009 concerning Mineral and Coal Mining, which requires reclamation and post-mining and these entrepreneurs cannot choose other options by utilizing the former mining pits as other uses such as housing or tourist attractions as mandated by the regulations below and the regional government of East Kalimantan Province. Then, the community around the mining pit must be able to respond quickly if there are negotiations carried out by coal mining entrepreneurs by submitting a complaint to the Department of Energy and Mineral Resources and the East Kalimantan Provincial Environmental Service.

\section{IV.CONCLUSION}

Prerequisites for the effective administrative law enforcement to prevent the violations of reclamation and post-mining obligations in East Kalimantan Province are as follows, first is to fix regulations regarding reclamation and post-mining obligations that must be carried out without leaving the mining pit. Second, optimizing the role of the Mining Inspector and the Department of Energy and Mineral Resources of the Province of East Kalimantan by adding human resources, operational budgets, facilities and infrastructure as well as accelerating the recapitulation of documents due to the transfer of mining authority from the Regency or City level to the Provincial Level. Third, efforts to eliminate the bad habits of the coal mining entrepreneurs aside from providing guidance to the coal mining entrepreneurs related to reclamation and post-mining obligations carried out by the Mining Inspector and the Department of Energy and Mineral Resources to the coal entrepreneurs that the closure of the mining pit must be carried out as a reclamation and post-mining activity and can also be done by involving the surrounding community in terms of supervising the reclamation and post-mining activities.

\section{REFERENCES}

[1] Rian Saputra, Adi Sulistiyono \& Emmy Latifah. Pendaftaran Internasional Sebagai Upaya Perlindungan Indikasi Geografis Indonesia Dalam Perdagangan Global (Studi Peraturan Pemerintah Nomor 22 Tahun 2018), Jurnal IuS Kajian Hukum dan Keadilan, Vol 7 Nomor 2 Agustus 2019.

[2] Rian Saputra dan Resti Dian Luthviati, Institutionalization of the Approval Principle of Majority Creditors for Bankruptcy Decisions in Bankruptcy Act Reform Efforts. Journal of Morality and Legal Culture. Vol. 1, No.2, December 2020

[3] Rian Saputra, 2020. Inventarisasi Potensi Indikasi Geografis Dalam Upaya Memperkuat Sistem Perlindungan Hukum Terhadap Indikasi Geografis di Indonesia (Studi di Provinsi Riau), Tesis, Magister Hukum Universitas Sebelas Maret.

[4] Rian Saputra. Development of Creative Industries as Regional Leaders in National Tourism Efforts Based on Geographical Indications. Jurnal Bestuur. Vol. 8, Issue 2, December, 2020.

[5] Rian Saputra, Pergeseran Prinsip Hakim Pasif Ke Aktif Pada Praktek Peradilan Perdata Perspektif Hukum Progresif. Wacana Hukum. Vol. 25, No.1 Juni 2019

[6] Siti Fatimah, Iswantoro, Udiyo Basuki, Rian Saputra, Abdul Kadir Jaelani. The Public Policy Of Local Government In Protecting Geographic Indication As A Leading Regional Product. International Journal of Advanced Science and Technology Vol. 29, No. 4, (2020)

[7] Ach.Tahir, Iswantoro, Siti Fatimah, Resti Dian Luthviati, Rian Saputra, Abdul Kadir Jaelani. The Model Of Criminal Policy To Customary Law Society After Decision Of The Constitutional Court Of The Republic Of Indonesia Number 95/PUU-XII/2014. International Journal of Advanced Science and Technology Vol. 29, No. 4, (2020).

[8] Muhammad Bagus Adi Wicaksono, I Gusti Ayu Ketut Rachmi Handayani, Lego Karjoko. Strengthening the government's Supervision in Coal Mining as Enforcement of Administrative Laws in Post and Mining Activities. International Journal of Advanced Science and Technology Vol. 29, No. 3, (2020).

[9] Muhammad Bagus Adi Wicaksono, I Gusti Ayu Ketut Rachmi Handayani, Lego Karjoko. Regional Government Supervision on Coal Mine Voids in East Kalimantan Province. International Journal of Advanced Science and Technology Vol. 29, No. 04, (2020).

[10] Muhammad Bagus Adi Wicaksono, I Gusti Ayu Ketut Rachmi Handayani, Lego Karjoko. State Policy's Analysis in the Redistribution of Reformed Agrarian Lands From Forest Areas in Indonesia (Study of Presidential Regulation Number 86 Year 2018 Regarding Agrarian Reform). Advances in Social Science, Education and Humanities Research, Volume 358.

[11] Siti Ummu Adillah, 2020, Regulasi Perlindungan Hukum Jaminan Sosial Ketenagakerjaan Bagi Pekerja Informal yang Berkeadilan, Disertasi, Program Doktor Ilmu Hukum Program Pasca Sarjana Fakultas Hukum Universitas Sebelas Maret Surakarta

[12] Jacob Park, Ken Conca, \& Matthias Finger, 2006, The Crisis of Global Environmental Governance: Towards a New Political Economy of Sustainability, New York: Routledge Taylor \& Francis Group 
[13] Jimly Asshiddiqie, 2009, Green Constitution: Nuansa Hijau Undang-Undang Dasar Negara Republik Indonesia Tahun 1945, Jakarta: RajaGrafindo

[14] Sulistyani Eka Lestari \& Hardianto Djanggih, Urgensi Hukum Perizinan dan Penegakannya Sebagai Sarana Pencegahan Pencemaran Lingkungan Hidup, Masalah-Masalah Hukum, Jilid 48 No.2, April 2019

[15] Itok Dwi Kurniawan, Muh. Bagus Adi Wicaksono, Wahyu Noviansyah, Enis Tristiana. Peranan Surat Pernyataan Tanggung Jawab Mutlak (SPTJM) Dalam Peningkatan Cakupan Kepemilikan Akta Kelahiran di Surakarta. Jurnal Kertha Semaya, Vol. 9 No. 10 Tahun 2021. 